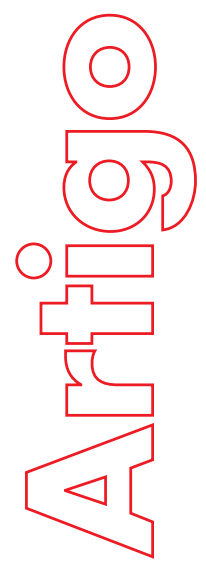

\title{
THE REORDERING IN RURAL SPACE
}

\author{
Marinês da Conceição Walkowski \\ Mirtz Orige Oliveira \\ Vinicius Boneli Vieira \\ Carlos Loch
}

p. $01-22$

revista

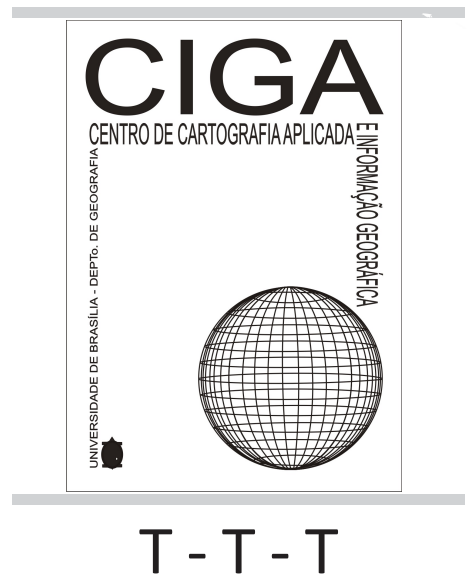

Revista Eletrônica: Tempo - Técnica - Território, V.5, N.2 (2014), 1:22 ISSN : 2177-4366

DOI: https:// doi.org/10.26512/ ciga.v5i2.15398
Como citar este artigo:

WALKOWSKI, M. C., Mirtz Orige Oliveira, Vinicius Boneli Vieira, Carlos Loch. THE REORDERING IN RURAL SPACE. Revista

Eletrônica: Tempo - Técnica - Território, v.5, n.2 (2014), p. 1:21 ISSN: 2177-4366. DOI: https://doi.org/10.26512/ciga.v5i2.15398

Available in: http://periodicos.unb.br/index.php/ciga/

Este obra está licenciado com uma Licença Crea tive Commons Atribuição-NãoComer cial 4.0 Inter nacional. 


\title{
THE REORDERING IN RURAL SPACE
}

\author{
Marinês da Conceição Walkowski \\ Bacharel em Turismo, Doutorado em Arquitetura e Urbanismo pela Universidade de Santa \\ Catarina, Brasil (2013). \\ E-mail: \\ marinesw@yahoo.com.br \\ Mirtz Orige Oliveira \\ Arquiteta, Doutoranda em Engenharia Civil pela Universidade de Santa Catarina, Brasil (2013). \\ E-mail: \\ Mirtz.orige@posgrad.ufsc.br \\ Vinicius Boneli Vieira \\ Bacharel em Turismo, Mestre em Geografia pela Universidade Federal do Paraná, Brasil \\ E-mail: viniciusbonelli@gmail.com \\ Carlos Loch \\ Professor, Dr. Departamento de Engenharia Civil pela Universidade de Santa Catarina, Brasil. \\ E-mail: \\ loch@ecv.ufsc.br
}

\begin{abstract}
The Brazilian rural area has potential for different activities is fundamental reordering in rural targeting the rearrangement of existing properties in an area in order to optimize the use of land observing ecological, social, and economic landscape. The objective of this work is to compare three redevelopment projects in rural areas developed in the highlands of Santa Catarina between 2001 and 2009. Currently the area of the mountain region of Santa Catarina is comprised of a set of eleven municipalities which experienced different methods of reordering. The methodology used in this study was the literature research, exploratory and descriptive in interviews in the field. It was concluded that for there to be viable in the redevelopment projects in rural areas it is necessary to take into account the economic, ecological and social. Many redevelopment projects were prepared without taking into account the basic principles, such as, improvement in quality of life and reduction of sprawl. Were observed, some difficulties with the lack of supervision of state agencies, the lack of qualified professionals for the design and implementation of projects and the low educational level of some social classes, inhibiting understanding and participation in the process.
\end{abstract}

Keywords: Rural; Reorganization; Multipurpose Technical Cadastre; Sierra Santa Catarina.

RESUMO: O espaço rural sul brasileiro apresenta potencial para a atividade turística em função das significativas belezas paisagísticas, riquezas culturais e a estrutura fundiária baseada em pequenas propriedades familiares cuja viabilidade econômica demanda a variação das atividades de forma pluriativa. No entanto, para que este potencial possa ser aproveitado é necessário dispor de informações sistematizadas e espacializadas que permitam ao usuário acessar e desfrutar dos destinos e equipamentos rurais. Neste sentido reside o desafio, para o planejamento territorial, utilizando o geoprocessamento de dados na tomada de decisões, buscar o fortalecimento de Joinville como cidade pólo na sua região turística. Neste contexto, o objetivo desta pesquisa é caracterizar fisicamente e espacialmente a microbacia do rio Piraí, utilizando Cadastro Técnico Multifinalitário (CTM) e Sistema de Informações Geográficas (SIG) para geoprocessar,

Revista Eletrônica: Tempo - Técnica - Território, V.5, N.2 (2014), 1:22 ISSN: 2177-4366 
fotointerpretar e analisar os dados provenientes da restituição aerofotogramétrica de 2010, visando apoiar o planejamento do turismo em uma área amostral do espaço rural de Joinville. Os métodos utilizados foram geoprocessamento de dados vetoriais e tabulares, fotointepretação de imagens aéreas e análise físico-espacial, tendo como ferramentas o CTM e o SIG, os quais foram trabalhados no software ArcGis 10. Nos resultados foram obtidos mapas temáticos de 3 propriedades com produção associada ao turismo. Concluiu-se que os resultados apontaram que o CTM, o potencial do SIG e das imagens de alta resolução são primordiais para o planejamento turístico na elaboração de mapas para divulgação do produto turístico local e diagnóstico de 3 propriedades com produção associada ao turismo.

Palavras chave: Turismo no Espaço Rural; Planejamento territorial; Cadastro Técnico Multifinalitário; Sistemas de Informações Geográficas; Joinville.

RESUMEN: La población rural del sur de Brasil muestra potencial turístico debido a la belleza escénica significativa, la riqueza cultural y la estructura de la tierra basada en las pequeñas explotaciones familiares cuya viabilidad económica de la variación de la demanda de actividades para pluriativa. Sin embargo, para que este potencial puede ser aprovechado es necesario contar con información sistemática y espacializado que permiten al usuario acceder y disfrutar de los destinos rurales y equipos. En esta dirección se encuentra el desafío de la planificación territorial, a partir de datos de SIG hora de tomar decisiones, buscar el fortalecimiento de la ciudad de Joinville como centro turístico en la región. En este contexto, el objetivo de esta investigación es caracterizar física y espacialmente cuenca del río Piraí, el uso polivalente Catastro Técnico (CTM) y el Sistema de Información Geográfica (SIG) para geoprocessar, fotointerpretar y analizar los datos de la devolución Aerofotogramétrico 2010, para apoyar la planificación del turismo en un área de muestra de las zonas rurales de Joinville. Los métodos utilizados fueron SIG vectorial y tabular los datos fotointepretação imágenes aéreas y análisis físico-espacial, con la CTM y herramientas SIG, que se presentaron en ArcGIS 10. Los resultados se obtuvieron mapas temáticos de 3 propiedades con la producción relacionada con el turismo. Se concluyó que los resultados indicaron que el CTM, el potencial de los SIG e imágenes de alta resolución son esenciales para la planificación del turismo en la elaboración de mapas de dar a conocer el producto turístico local y diagnóstico de 3 propiedades con la producción relacionada con el turismo.

Palabras clave: Turismo Rural, Planificación Territorial, Catastro Técnico Polivalente, Sistemas de Información Geográfica; Joinville.

\section{INTRODUCTION}

According Aurelio Dictionary of Portuguese, the verb reordering means "put them back into order; make arranging; disposal." Thus, the reordering in rural areas can be defined as the rearrangement of existing properties in an area in order to optimize the use of the ground observing the ecological, social, and economic landscape.

The design of the physical and legal private properties has been discussed in many places in the world. The reordering of rural and urban spaces is developed in Germany, Japan, the Netherlands, China and the USA (HONG; NEEDHAM, 2007). Also in Brazil there are experiments in this direction.

In many places the soil is not used optimally. This is often because the property is understood as absolute, ie, because the owners believe they have the right to use it without worrying 
about public and collective aspects. This attitude can lead to several negative consequences for society, such as under-utilization of productive spaces flout environmental laws and sprawl. The use of private property rights should be mediated by the state, such as environmental laws, and neighborhood rights, not only in urban but also in rural areas. However, when the negative situation is already established is still possible to reorder.

In general, it is possible to point out reasons to reorder rural areas:

a) Facilitate access to land for all;

b) Improve the infrastructure for population and agricultural production;

c) Avoiding urban sprawl on rural areas;

d) Improving primary production;

e) Arrange transportation network for runoff farming.

According to Neumann (2003), goals are reordering processes: promoting the conditions to develop more efficient agriculture and increase the possibilities for forestation; foster conditions for agricultural efficiency and for the protection and management of natural areas; promote increased production and improvement in working conditions, reforestation, management and land use planning and the layout and structures of rural areas according to the various functions.

For the purposes of a reorganization process in rural areas are reached it is necessary to consider some feasibility criteria. One of these criteria is economic viability. It is important to note the economic activities in the region to be reordered and consider the characteristics necessary for the continuity and improvement of these activities. In this sense, one should evaluate the relationship between the ideal and actual units of agricultural production and the influence of geometry in this production.

Another criterion to be considered is the ecological viability. Agricultural activity is essential to meet the needs of human life. However, this activity is based on the use of renewable and non-renewable. Without entering into the merits of the discussion on the use of non-renewable resources, any proposed redevelopment should consider the importance of legally protected areas in rural.

Finally, it is still necessary to observe the criteria of social viability. It is important to consider several aspects to ensure the quality of life of the population that occupies the area to be 
reordered. Among these aspects is possible to mention the scenery, the collective uses and cultural aspects.

In the context of this discussion, the aim of this work is to compare three redevelopment projects in rural areas developed in the highlands of Santa Catarina between 2001 and 2009.

\section{POSSESSION OF LAND IN BRAZIL}

In Portugal, the prevailing philosophy of stimulating primary production. Since the fourteenth century, there was a legal provision that allowed the Portuguese government to expropriate unproductive land. Brazil became a colony of Portugal from 1500. The first attempt to land the new territory was the implementation of the system of hereditary captaincies. This system has been adopted in many Portuguese colonies and was based on the principle privatístico property. (LOCH; ERBA, 2007).

These captaincies were subdivided into parcels called Sesmarias with its respective title, Charter Sesmaria. These parcels were donated to candidates intending to settle the soil, endowed with management and negotiation skills, delegating powers and privileges as the Captaincy status (Medeiros, 2002). It was from that branched Sesmarias the Brazilian real estate (LOCH; ERBA, 2007). The demarcation of land grants was problem that has lasted for centuries. Among the main difficulties is possible to mention the cost of officials appointed to the function of demarcation, as well as difficulties related to the lack of colonial territory. Even so, they continued to be issued letters of allotments, based on inaccurate information. This led to many problems, such as areas with different sesmeiros nominated occupation of public lands and the emergence of large estates (Marighela 1980).

The idea of stimulating primary production and land use in Brazilian territory by granting Sesmarias persisted until 1822. This year, a resolution (No. 76 of July 17, 1822) suspended the grant. According Loch and Erba (2007), thereafter the possession and occupation of lands abound. Even with the Imperial Constitution of 1824 this situation was not resolved. In this situation the Brazilian Imperial Government in 1850 enacted the Land Act (No. 601 of September 18, 1850). This law began construction of a system of administrative organization of Brazilian lands, from the discrimination between public and private lands. Had about the purchase and sale of lands of the State and revalidation of land ownership by title Sesmarias, among other topics (LOCH; ERBA, 2007).

The Land Law was legislated in 1854 by Imperial Decree of 30 November 1318. This decree created the General Bureau of Public Lands that had be: measuring public lands; legitimize Revista Eletrônica: Tempo - Técnica - Território, V.5, N.2 (2014), 1:22 ISSN: 2177-4366 
private lands and the sale of public lands, instituting the system of control of public lands, and create the parish register. (LOCH; ERBA, 2007). Furthermore, this law established the Land Registry Held that required all owners with property titles or possession to register their land. However, the plant was not required measurement at registration. (LOCH; ERBA, 2007). In 1890, Decree 451B demanded registration of any action to modify the area in question. This decree provides still on the plant and property valuation. Established the need for setting benchmarks stable to allow the incorporation of estate plan with the Charter General Cadastral among other important details (LOCH; ERBA, 2007).

From the Republican Constitution of 1891, public lands were delegated to the federal states. Thus, the states became responsible for legislating on matters of public domain lands. This was reaffirmed by republican constitution of 1931 (LOCH; ERBA, 2007).

Few legal mentions had been made with regard to the mechanisms of agricultural restructuring in Brazil until the law no. 45041964 call Land Statute. This law regulates various aspects related to land reform, the rights and obligations related to rural properties. In addition, the opportunity to ensure access to land to all, conditioned by its social function, as part of the national agricultural policy (LOCH; ERBA, 2007). Foresees the need for zoning and land records involving the public, private, squatters and unoccupied. Also was this legislation that created the Register of Rural Properties Brazil (LOCH; ERBA, 2007). This status proposed for the first time in Brazilian law, the use of credit as a form of land access to land through the purchase and sale of rural properties with long-term public financing and subsidized.

In 1969, the decree-law no. 554, regulated by the law. 5868, 1972 and Decree no. 72106, 1973, dealt with the expropriation of rural land reform in order to fulfill the social function of property. In 1970 the National Institute of Colonization and Agrarian Reform (INCRA) and Registration System which included the National Rural Rural Property Register, Register of Owners and Holders Rural property, Register of Tenants and Rural Partners, Register of Public Lands (LOCH; ERBA, 2007).

In the 1980s, the reordering in rural areas began to be discussed through the preparation of the National Land Reform Decree no. 917661985 (LOCH; ERBA, 2007). The purpose of this plan was to promote social justice, increase production, increase food supply, creating new jobs and reduce the rural exodus sat million families in 15 years (Graziano da Silva, 1985). 
In 1988, new federal constitution was promulgated. In his chapter called Economic and Social Order, Article 184, was guaranteed the social function of land through expropriation of rural land unproductive, causing environmental degradation and do not respect the rights of workers (MILK, Avila, 2007). Expropriation guarantees the right of the former owner for compensation in Agricultural Debt (TDA), receiving annual installments in accordance with the value of land in a period ranging from five to 20 years according to the size of the area. This process became known as expropriations redistributive land reform. However, they did not set the criteria for the determination of unproductive properties, generating controversy and the possibility of legal action on foreclosures (PEREIRA, 2009).

At this time, the Movement of Landless Workers (MST) sought greater integration into the national and international political scene, with the increasing number of camps and raids conducted in Brazil (PEREIRA, 2009). The purpose of these actions was related to compliance with Brazilian legislation on agrarian reform.

From the 1990s, the process of political and administrative decentralization has strengthened the defense of federal reorganization of rural Brazilians from the voluntary credit programs regulated by the state as an alternative mechanism of expropriation (Medeiros, 2002). Examples of this type of initiative to institutionalize bags lease and partnership, and regulation of land purchase.

Influenced by the growing number of invasions of property and popular demonstrations in favor of reform, some actions were undertaken experimental reordering through credit programs. One of these actions occurred in 1997 in the state of Ceará and was promoted by the World Bank, the pilot São José (PEREIRA, 2004). From this experience created the temporary program called the Land Title. This program covered five states of Brazil, Maranhão, Pernambuco, Bahia, Minas Gerais and Ceará (BRANDÃO, 2000; PEREIRA, 2004).

Complementary Law No. 93 of February 4, 1998, created the Fund for Land and Agrarian Reform, also called the Land Bank permanently. This fund was intended land acquisition by farmers with poor access to land. The management of this fund was held by a Board of Trustees comprised of seven Ministers of State, the President of the National Bank for Economic and Social Development (BNDES), the president of INCRA and two representatives of rural workers (PEREIRA, 2004; CAMARGO, 2003).

More recently, in the law. 102672001 dealt with the deployment of the National Register of Rural Properties associated with georeferencing properties. This law was a milestone for effective integration between cadastre and property registry (LOCH; ERBA, 2007). The requirement of cartographic products to compose membership is extremely important to create the basis for government policies in rural redevelopment. According Loch and Erba (2007), one of the main problems with the registration of properties in Brazil is the lack of connection between the property Revista Eletrônica: Tempo - Técnica - Território, V.5, N.2 (2014), 1:221 ISSN: 2177-4366 
records and cartographic documents produced by professionals. Thus, we can not say about the correlation between the reality of the field (effective possession) and acquired right (title deed). Thus, it is difficult to intervene in the form of redevelopment because there are few reliable data on the actual situation of Brazilian rural areas.

In 2003, new institutions have been created to address the issues related to the restructuring of rural areas, the National Agrarian Reorganization (SNRA) and the Department of Agrarian Credit (DCF), both linked to the Ministry of Agrarian Development (MDA) (PEREIRA, 2009). These two governmental institutions aimed at enabling the existence of two (2) forms of reorganization in rural areas in Brazil: a redistributive land reform and land credit programs. Therefore, launched the Second National Plan for Agrarian Reform (PNRA). The innovation of this plan was the inclusion of family farmers, traditional rural communities, coastal communities, affected by dams and other works of great infrastructure, non-indigenous occupants of the indigenous areas, rural women workers and rural youth and other groups that inhabit rural municipalities, but not dedicated to agricultural activities, such as public redevelopment projects in rural areas.

Even with these restructuring initiatives, the results of the 2006 Brazilian agricultural census showed the high degree of inequality in the distribution of land ownership in Brazil (IBGE, 2006). According to this study there is more than 4.9 million agricultural establishments with an area declared that occupy 330 million hectares. The average area of these establishments is 67.1 hectares. Establishments with less than 10 hectares accounted for 50.3\% of total and occupied 2.4\% of the total area. Already establishments with more than 1,000 hectares accounted for less than $1 \%$ of the total and $44.4 \%$ of the area occupied.

Also in this study, the Brazilian Institute of Geography and Statistics (IBGE) defined four categories related to condition of land tenure: owner, tenant, occupant and partner. Observing the temporal evolution of the characteristics of rural property in Brazil is possible to see the growth of the number of owners who accounted for $64.1 \%$ of establishments in 1975, 74.5\% in 1995/96 and 80.2\% in 2006. Among the agricultural census of 1995/96 and 2006 the average area of farms category of owners fell from 92.0 ha to 77.8 ha. Already the average size of establishments in categories tenant, partner and increased occupant.

Since the Empire, the Brazilian territorial legislation aimed demarcation and registration of real estate components of public and private property. Despite the need to reorder the Brazilian 
territory is an issue perceived and discussed in Brazil for a long time, only from the 1960s this topic began writing specific legislation. Since then, some mechanisms have been developed for reordering in rural areas in Brazil. Currently, redevelopment projects are related to land reform, the construction of engineering works or the use of instruments such as land credit provided in public policy. The reorganization related to agrarian reform is redistributive, ie considered unproductive properties are expropriated and their areas parceled among farm families. The reordering occurs related to major works from negotiations between entrepreneurs and affected populations. Already reordering from land credit programs enable the acquisition of land by farmers through government funding of long-term.

The Brazilian has territorial diversity of laws on the subject. But the practicalities have not been able to resolve negative situations exist. One reason for this fact may be related to the low state intervention in land.

\section{SANTA CATARINA AND POSSESSION OF LAND}

The occupation of the territory of Santa Catarina is related successive migratory waves that contributed to the colonization of Brazil. Until the eighteenth century the occupation of the territory of Santa Catarina was almost exclusively indigenous. Only coastal areas were occupied by small villages with Europeans and their mixed descendants of the local indigenous populations.

The territory allows us to recognize the social processes, especially with regard to mothers most expressive ethnic population and the expropriation of spaces. Thus, the territory bears the marks of the past, the current dynamics and power lines that show what can happen in future space (FERREIRA, ANGELS, 2012).

Throughout the nineteenth century, the political and intellectual elite Brazilian viewed a way to boost the country the "later stages" both socially and economically: immigration. Through the coming of immigrants would be replaced gradually, slave labor and by miscegenation, could - if whiten population, and hence, a type genuinely Brazilian. The European immigrant would be best suited to these goals (Seyferth, 2000). The binomial immigration-colonization was quite strong during the Empire and the Republic follows. The political and intellectual elites wanted immigration to Brazil farmers preferred white Europeans in the country that could deploy a new form of agricultural production based on small property (Seyferth, 2000).

In this period began to arrive in Brazil, new waves of immigrants, mainly from the regions of present-day Germany and Italy. Many of these immigrants were brought to St. Catherine which were established in the major river valleys of the coastal plain. The demarcation of the land Revista Eletrônica: Tempo - Técnica - Território, V.5, N.2 (2014), 1:22 ISSN: 2177-4366 
occurred in the line system, which followed into the valleys of the rivers and streams. In general, we can say that from this system of colonization developed predominantly in rural Santa Catarina small property characterized by family labor.

From this migratory process Santa Catarina became a multi-ethnic state with different realities and agricultural land. Many descendants of these immigrants were able to land ownership by granting land titles. But many farmers remained in informal situations as tenants, squatters or occupiers of land.

The first actions related to land Santa Catarina were made in the twentieth century. The State Decree. 82, 1931 and Decree no. 46, 1934 created and regulated Parcelling Territorial Cadastre for the record and the record owners of the parcels owned in Santa Catarina (LOCH; ERBA, 2007).

In the 1970s, new strategies aimed at reordering actions in rural areas began to be discussed in state government. From these discussions, it was created the Land Fund of Santa Catarina. This fund was established by Law No. 6288 of October 31, 1983 and regulated by Decree No. 20.842 of December 16, 1983. Its objectives were to ensure access to land through the purchase of land by squatters, tenants, sharecroppers, sons of small farmers, fisherfolk, cooperatives or associations representing these categories (Cazella, 1995; CAMARGO, 2003; CONDÉ, 2006). The use of this fund led to the fulfillment of the contract $59.42 \%$ in 20 years. Other contracts were $14.56 \%$ and $19.15 \%$ were abandoned or transferred are in judicial execution. As the profile of the beneficiary public, $82 \%$ were tenants, $11.62 \%$ were children of small farmers and rural workers were $6.10 \%$. Through this fund acquired $73 \%$ of the areas were incorporated into the production process, accounting for $2.7 \%$ of the total productive area of Santa Catarina.

On June 17, 1992, through the Farm Bill No. 8676 the Land Fund was included as an instrument of agrarian policy Catarina. The basis of this background influenced the creation of the Land Bank. During this decade began to be deployed in the state the National Land Credit (PNCF). Until July 2009, were met by this program 5,338 families (PEREIRA, 2009).

Other rural areas in Santa Catarina were reordered due to engineering works, mainly hydroelectric plants. Also social movements active in the state were able to pressure the government and settling families in different regions of the state, primarily in the mountains and highlands of Santa Catarina (BOEIRA, 2006, MDA, 2009). 
Santa Catarina has a high incidence of farms managed by farmers and an agricultural frontier closed, with few areas for expropriation for unproductive, but with several areas for buying and selling (PEREIRA, 2009). With regard to the reordering in rural areas, it is possible to realize St. Catherine presents a situation similar to the rest of the country. It can be argued that there is little state intervention in order to reorder rural areas to meet their social function, increase agricultural production, improve the infrastructure of rural areas or avoid urban sprawl.

\subsection{The mountain region of Santa Catarina: experiences of territorial reorganization}

The mountain region of Santa Catarina has climate is Cfb, according Köeppen, ie temperate constantly moist, without dry season, with cool summer. The average annual temperature ranges from 13.8 to $15.8{ }^{\circ} \mathrm{C}$, with maximum between 19.4 to $22.3^{\circ} \mathrm{C}$ and minimum between 9.2 to 10.8 oC. The annual total rainfall 1360-1600 mm, with a total annual rainfall between 123 days and 140 days. The annual total insolation can vary 1824-2083 hours. The primary vegetation prevalent in the region were in the fields with capons, riparian forests and pine forests, with a predominance of herbs (Grasses, Sedges, legumes and Composite). The existing vegetation consists of fields interspersed with areas of annual crops and forest remnants (EPAGRI 1999).

The fitness class is predominantly agricultural to three (3), with $43.5 \%$ of the total area. This ability is constrained to annual crops, fruit trees for regular fitness and good suitability for grazing and reforestation. The major limitations to agriculture are stoniness and fertility. Agricultural production in the region has a predominance of livestock, under the extensive system of basic staples such as corn and beans. Another important activity is the reforestation with Pinus sp for supply of raw materials to the industries of cellulose and its derivatives (EPAGRI 1999).

The mountain region of Santa Catarina was occupied initially by Ge indigenous language for over 2000 years. From 1730, the gold exploration in Minas Gerais created a demand for cattle, horses and mules. In this context, the mountain region of Santa Catarina became staging area troops of these animals from Rio Grande do Sul bound the fair in Sorocaba (SP). Some troops were in the area for long periods and some drovers stayed in the region becoming farmers and ranchers. In 1766, we built a town called Vila de Nossa Senhora dos Prazeres the packings, the present city of Lages (Peixer, 2002). The construction of this village was related to the occupation of the strategic position of defending the territory colonial South - Brazil in relation to the Spanish.

The occupation of this region was characterized by little enclosed spaces, where farm workers circulated freely, establishing their possessions. This process established a social hierarchy consisting of farmers and their families (owners of land dedicated to livestock, with numerous Revista Eletrônica: Tempo - Técnica - Território, V.5, N.2 (2014), 1:22 ISSN: 2177-4366 
aggregates), the creators (also owners, working with the help of family and two or three pawns), small farmers who planted using family labor, households receiving in-kind payment for its work, pedestrians and persons working in livestock (Bloemer, 2000). This structure supported the local economy until the 1940s.

Also in this region were granted Sesmarias, with an area equivalent to approximately 10,800 ha. Various forms of informal land tenure were used by other components of society fields Lages. The Land Act 1850 extinguished the allotments and demanded demarcation of land. This event difficult access to land by the poor. Moreover, this population grew on poor families coming from other regions of conflict over land (MUNARIM, 1990).

Abramovay (1992) pointed out some constituent society of the mountain region of Santa Catarina. Unlike other areas of the state, there was consolidation prosperous family farm as a region of fields and flocks passing custom dependency between pedestrians and landowners. Moreover, they are local characteristics of poor access to land, information, markets and knowledge. This helps explain the great poverty of the region.

Currently the area of the mountain region of Santa Catarina is comprised of a set of eleven municipalities: Panel, Bocaina South Otacílio Coast, Palm, Pinto Correia, Lages, Sao Jose do Cerrito, Capon Alto, Campo Belo do Sul, Cerro Negro and Anita Garibaldi as shown in figure 1. All these municipalities were created from the dismemberment city of Lages. 

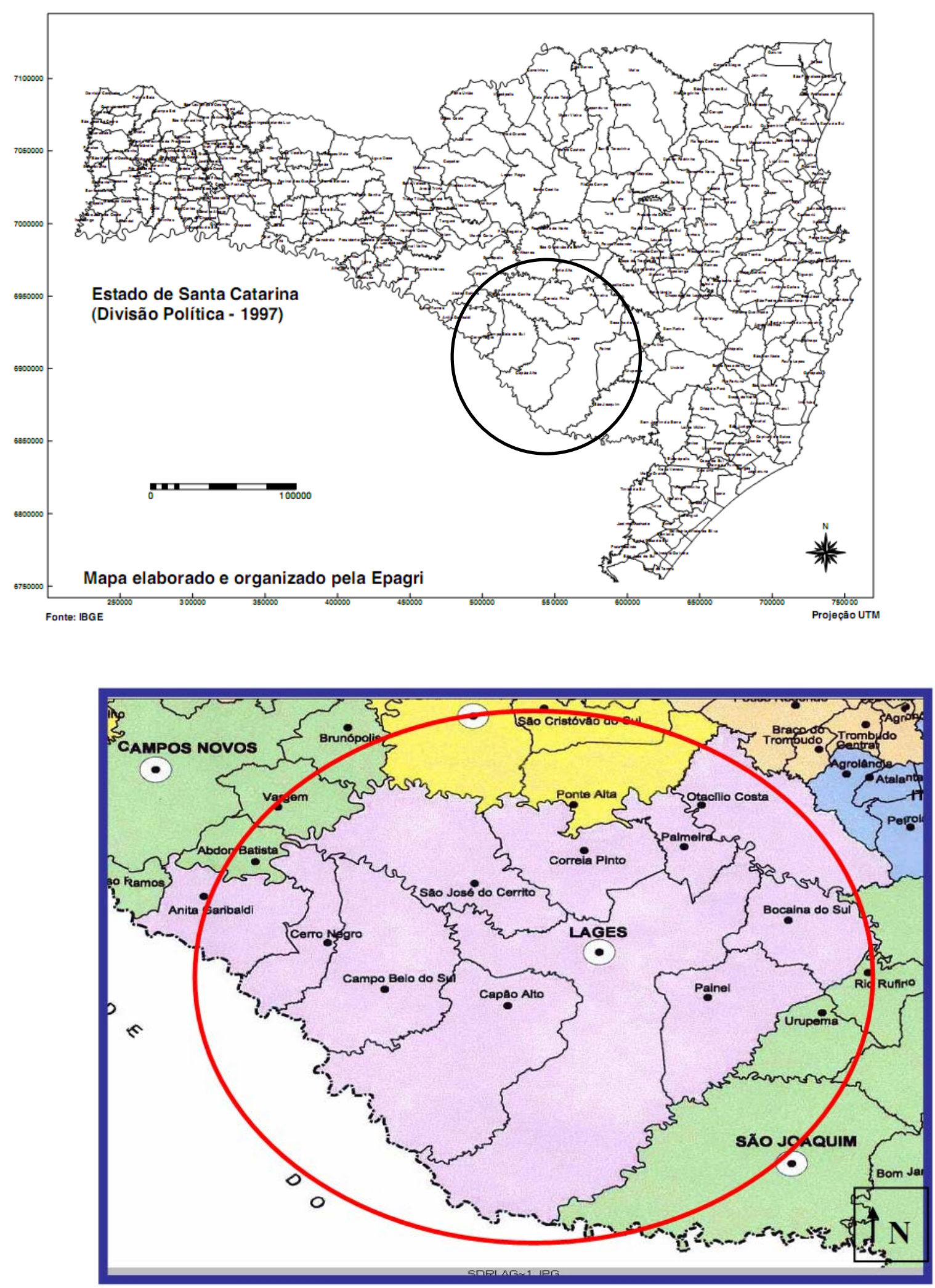

Source: Government of the State of Santa Catarina (2009)

Figure 1. The Planalto Serrano of Santa Catarina

This region have developed some projects reordering in rural areas. These projects have used different methods to select participants and acquire the areas to be reordered. However, they all share the core objective of providing access to land for the rural impoverished. One of these Revista Eletrônica: Tempo - Técnica - Território, V.5, N.2 (2014), 1:22 ISSN: 2177-4366 
projects is related to land redistribution forced by social movements. Another project is linked to the restructuring of rural land due to a large piece of infrastructure. The last project to be analyzed concerns the use of a tool for redevelopment in rural areas, the land credit.

\subsection{The process of restructuring in rural areas by redistributing}

The role of social movements as MST, Via Campesina, Movement of Rural Women and others forced the reorganization of areas for redistribution throughout Brazil. In Santa Catarina there are several examples of this. However, in the highlands of Santa Catarina reordering based on expropriation of unproductive areas and redistribution to landless families is not a mechanism widely used (Pereira, 2009). In this region, there are only three (3) projects of this type of rearrangement, which corresponds to $3 \%$ of the total performed in Santa Catarina. The first happened in the town of High Bridge in 2003. Was expropriated a farm with an area of more than 520ha redistributed to 45 families. The second project was implemented in the municipality of Correia Pinto in an area larger than 1.160ha. As of 2006, there were 70 families settled in this area (INCRA, 2008).

In Campo Belo do Sul has run the most recent project. In this municipality, 2.5\% of properties are above 500 ha, but hold 39\% of the total area of the municipality. In January 2008, Fazenda Santa Cruz with over 907 ha was invaded by the MST families. After establishing houses on the farm, has formed a committee of workers who sought the city government and INCRA requesting deployment electricity, education for children in the camp and the establishment of the redevelopment project area by redistribution. The goal was to redistribute land to 45 families from Lages, Otacílio Costa, Curitibanos and other regions of the state.

In July of the same year, the regional superintendency INCRA in Santa Catarina imitida was in possession of Fazenda Santa Cruz. Then was published ordinance creating the settlement project and the selection of beneficiaries. Finally, families have signed settlement agreements and received initial support credits. During the first year, INCRA technicians and Technical Assistance, Social and Environmental (ATES) prepare the Development Plan Settlement (PDA) to drive economically sustainable development area (MDA, 2009). 


\subsection{The process of restructuring in rural areas due to engineering works for infrastructure}

Since the 1960s, the Brazilian federal government has a policy of energy hydropower plant construction. Nationwide to various plant were built over the last 40 years. In the highlands of Santa Catarina there was the construction of a power plant, Barra Grande.

Boeira (2006) researched the reordering caused by the construction of this engineering work. The bus was built in Pelotas River $43 \mathrm{~km}$ from the confluence with the River Canoes. The plant is between the states of Santa Catarina and Rio Grande do Sul area of direct and indirect influence encompassed the municipalities of Anita Garibaldi, Cerro Negro, Campo Belo do Sul, Alto Capon and Lages. Since the authorization to carry out feasibility studies, in the 1995th year of the beginning of the project, appeared in the area of civil society organizations, as trade unions, farmers' associations and social movements as MMA and MAB.

The analysis of rearrangement in rural areas related to the construction of the hydroelectric plant of Barra Grande revealed three important processes. The first case occurred between the late 1960s and the year 1995. Public knowledge of electric sector projects for the region of the Uruguay river basin has generated significant mobilization for future action of some social actors. At this time arose groups with different interests and forms of action stakeholders in the enterprise: a) group of private, b) governmental institutions and political-administrative, and c) a group of nongovernmental civil society organizations, linked directly to the interests rural population affected by HPP (BOEIRA, 2006).

The second case occurred between the years 1995 and 2001. Earlier this period was granted the license for carrying out technical feasibility studies, economic and environmental project HPP Barra Grande. Also at that time was published the list of farm families be they owners or not, which areas would be affected by the construction of the plant. According to the registration done, the municipality of Anita Garibaldi concentrated about 50\% of the total number of affected families (184 families). Were also affected families in the municipalities of Cerro Negro (109), Campo Belo do Sul (51), Capon Alto (42) and Lages (4 families). Thus, the reorganization of this area included three hundred and ninety (390) families (BOEIRA, 2006).

With the release of this record physical and symbolic transformations occurred in rural areas, as the first expropriations, the fragmentation of social groups and the inclusion of new groups, especially employees of contractors and service providers (Boeira, 2006).

From 1997, there was an intense performance of the group of governmental institutions and political-administrative, associated with the private sector, as well as the group of nongovernmental entities linked to the interests of the rural population. Governmental institutions and political-administrative mobilized to support the construction of the dam. There were three (3) Revista Eletrônica: Tempo - Técnica - Território, V.5, N.2 (2014), 1:22 ISSN: 2177-4366 
public hearings and open meetings called Pro Forums HPP Barra Grande to disseminate information about the project to the population (BOEIRA, 2006).

On the other hand, non-governmental entities to support rural communities sought to clarify farmers and rural workers of their rights of ownership and use of their lands. In addition, the organization sought to encourage these farmers to negotiations on the sale and / or indemnification of its properties and desktops (BOEIRA, 2006).

The last case reported by Boeira (2006) started from the year 2001, with the release of the Installation License (LI) and the concession for the hydroelectric potential of the river Pelotas. In this period, there were concrete actions to build the dam. The progress of the works also promoted the progress of negotiations for reorganization. The construction company was in charge of leading the negotiations with farmers. Farmers interviewed by Boeira (2006) felt aggrieved that the negotiations were conducted individually.

With that farmers, organized by MAB, started to pressure the company through lawsuits. A key demand was the explanation of the evaluation criteria of the property gazing beyond economic values also symbolic values. At the end of 2002, the company negotiated with the MAB and formalizoualgumas guidelines that would be the basis for future operations. These guidelines were formalized in the document called an Agreement for the Resettlement of Affected Population by Barra Grande Hydropower Plant. However, this agreement was not fulfilled generating new lawsuits in 2003. This action is extended until the end of 2004. This year political negotiation between the Ministries of Environment, Mines and Energy and the Civil House of the Presidency, established compensatory concrete actions to be performed by the company both in regard to the reorganization of the countryside as environmental damage resulting from formation of the reservoir lake. New lawsuits were undertaken by non-governmental organizations aiming to ban the work. The result of these actions was the signing of the Commitment to continue the reorganization process respecting the requirements of farmers (Boeira, 2008). This process ended only in 2008, when they were published ordinances recognizing the INCRA settlement projects related to Barra Grande dam (INCRA, 2008).

\subsection{The process of restructuring in rural areas using the land credit}


In the municipality of Cerro Negro projects were never executed agrarian reorganization through distribution. According to IBGE (2008), the municipality of Cerro Negro has a population of 4,053 inhabitants and a population density of 9.46 inhabitants / $\mathrm{km}^{2}$. Although the population is predominantly rural (83\% in 2000), is intensifying migration to other regions, the process started from the 1970s. The city has a per capita income average, three times lower than the median income of Santa Catarina. The number of poor people in rural areas is 73\%, and approximately half of the population is considered without sufficient income to ensure their own food. The Municipal Human Development Index (HDI - M) is 0.687, second to last among the 293 municipalities in Santa Catarina.

The municipality has a structure smallholders approximately 90\%. There are only seven (7) facilities with more than 500 acres that occupy 27\% of the total area. A total of 994 production units of the municipality, $97 \%$ are managed by farmers, of which $76 \%$ live on less than one minimum wage per month. As the condition of land ownership, the category of owners holds $94.24 \%$ of area and $72.5 \%$ of the total establishments. The city presents farmers with low access to land (tenants, partners and occupiers).

The research of Pereira (2009) sought to analyze the ongoing reorganization of rural areas in the municipality of Cerro Negro from the use of land credit. The initiative to use this instrument came from reordering interested. 70 projects were proposed for funding to purchase land from the land credit program in this county. Of these, 30 projects were proposed by small landowners and the other 40 projects were entered for tenants and leaseholders. Only two projects were approved, one of these was executed quickly and the other waited over 12 months for the release of funds. Of the remaining 28 projects are still under evaluation, all inscribed by small landowners. The other 40 projects proposed by tenants and squatters were denied.

To understand the process, we interviewed 34 people from three different social groups of Cerro Negro. The first group of informants consisted of six technicians and leaders of local institutions (EPAGRI Family House Rural Development Associations Microcatchment and Rural Workers Union) that make up the Municipal Rural Development, a body responsible for the participatory strategic planning agriculture in Brazilian municipalities. The second group of informants consisted of 11 potential users of the instrument land credit. Among the potential users were tenants, leaseholders and individuals who own land inheritance with public deeds not disrupted in five different rural communities (Cruzeirinho, Beneditos, Umbú, Sacred and Araça). The third group of informants consisted of 17 members of three community associations, most children of small landowners in the municipality. For all groups were asked questions about the process of mobilization, access and operation of land credit (PEREIRA, 2009). 
The results obtained allow to realize that there is a process of selecting individuals to participate in redevelopment projects in rural areas from the lending of land in the municipality of Cerro Negro. For this instrument to be used, the persons concerned must meet the program and establish relationships with CMDR that validates the claims. Regarding the criteria for participation in the program, the spontaneous application has been named the best selection because persons with initiative, able to understand the rules of the program and have a lower risk of non-payment (PEREIRA, 2009).

This dynamic favored the small landowners. Only this category of rural workers had their projects approved. In general, the owners have higher level of formal education which enables him to make proposals and understand the rules of the program. Additionally, these people have higher social articulation with the leaders of Cerro Negro present in CMDR, are able to demonstrate the ability to pay (PEREIRA, 2009). On the other hand, the dynamics of the ongoing reorganization of Cerro Negro from the land credit reduction in relation squatters and tenants. This population has a low level of formal education and are not involved in social organizations, trade unions and political decision-making that make up the board. This hindered the access of this group to the program since struggled information about the program. Furthermore, the lack of skilled personnel for the preparation of funding proposals in CMDR hindered the participation of this portion of the city population. Finally, squatters and tenants had difficulties in demonstrating ability to pay off financing due to the predominance of informal work. No project proposed by this group was approved (PEREIRA, 2009).

\section{FINAL CONSIDERATIONS}

By comparing the redevelopment projects in rural areas occurred in the highlands of Santa Catarina is possible to highlight some features. All projects sought to cater mainly to the goal of providing access to land for all. The exception of the project related to the construction of hydropower in other projects not contemplated the improvement of infrastructure to population and agricultural production did not improve primary production, and have not sought to avoid uncontrolled growth of human occupations. Thus, we can say that these goals are not present in the preparation of projects. The explanation for this may lie in the lack of qualified professionals 
preparing such projects (HONG AND NEEDHAM, 2007). As described in many projects the population interested in reordering was responsible for the preparation of projects. The government only assessed, approving or discarding such projects.

When reordering in rural areas is conducted in this way there are great chances that there is no feasibility for implementation. It is possible that these projects described have been concerned only with economic viability, since farm families needed to know the economic activities in the region to be able to enter their productions on the market with marketing conditions. However, as regards the ecological viability only areas reordered by INCRA receive technical assistance and supervision often related to compliance with Brazilian environmental legislation. The other areas are audited by the state of the environment that has deficiencies personnel and infrastructure to do so. In the referred social viability, access to land is considered essential aspects such as landscape Usage and collective cultures are often treated as secondary. Sparovek (2003) points out that in the process of reorders ment redistributive government policies favor the acquisition of land and the settlement of families and undertake little investment in actions that contribute to improving the living conditions and economic production of projects.

According to Hong and Needham (2007) there are two viable alternatives for the territorial reorganization: a voluntary exchange or the public intervention in the form of expropriation. In Santa Catarina is possible to see variations of these alternatives. The land credit combines state action through the establishment of public policy and funding voluntary action of the parties. This strategy of reordering can be an interesting alternative for groups that have no link with the social movements that promote redistributive reordering. Your application would allow access to the land of the children of farmers with small farms, whose estate was insufficient for agricultural production.

The redevelopment with the construction of engineering works associated with state intervention that forces entrepreneurs to negotiate the displacement of affected populations and community participation of farmers organized to negotiate the terms of the displacement. Finally, the reordering through expropriations and splitting of large unproductive properties also combines government action through legislation and action of the body responsible for land reform, with the social action of the families of landless farmers.

Thus, in the study area state intervention was not the motor processes of reordering. In fact it is the role of the state in Brazil to ensure life safety. Many of these goals can be achieved through the territorial reorganization. However, the main difficulty is how to reorder gather private property rights. 
The analysis of the redevelopment projects in rural areas occurred in the highlands of Santa Catarina can bring contributions to the debate on reordering applications in complex situations that require solutions more efficient and fair than those possible by tools that exist today.

\section{REFERENCES}

ABRAMOVAY, R. Paradigmas do capitalismo agrário em questão. São Paulo: Hucitec, 1992.

BOEIRA, S.M. Estudo da Dinâmica Territorial Rural: a implantação da usina

hidrelétrica Barra Grande no planalto sul catarinense. 103f. Dissertação (Mestrado em Agroecossistemas) - Centro de Ciências Agrárias, Universidade Federal de Santa Catarina. Florianópolis, 2006

BLOEMER, N.M.C. Brava Gente Brasileira: migrantes italianos e caboclos nos Campos de Lages. Florianópolis: Cidade Futura, 2000.

BRANDÃO, W. A reforma agrária solidária do Ceará. Brasília: Ministério do Desenvolvimento Agrário. Reforma Agrária e Desenvolvimento Sustentável, 2000.

CAMARGO, L. O Banco da Terra em Santa Catarina: da crítica às possibilidades. Dissertação (Mestrado em Agroecossistemas). Centro de Ciências Agrárias, Universidade Federal de Santa Catarina. Florianópolis, 2003

CAZELLA, A.A. Trajetória de desenvolvimento e caracterização socioeconômica da região serrana de Santa Catarina. Relatório de Projeto de Pesquisa, 2006.

CONDÉ, P.A.A. Acesso a terra e a visão do público não mobilizado em acampamentos: 0 crédito fundiário do município de Caçador - SC. Dissertação (Mestrado em Agroecossistemas). Centro de Ciências Agrárias, Universidade Federal de Santa Catarina. Florianópolis, 2006. 
EPAGRI/CIRAM. Empresa de Pesquisa Agropecuária e Extensão Rural de Santa Catarina. Zoneamento Agroecológico e Socioeconômico. Florianópolis: Epagri, 1999.

FERREIRA, C. L; ANJOS, R. S. S. O território dos maracatus-nação de pernambuco: interpretação preliminar. Revista Tempo, técnica e território. v. 3, n. 1, p. 46-80, 2012.

HONG, Y.H.; NEEDHAM, B. Analyzing Land Readjustment: Economics, Law and Collective Action. Cambridge, MA: Lincoln Institute of Land Policy, 2007.

IBGE. Instituto Brasileiro de Geografia e Estatística. Censo 2006. Disponível em www.ibge.gov.br. Acessado em 12 dez 2009.

IBGE. Instituto Brasileiro de Geografia e Estatística. Mapa de Santa Catarina. Disponível em www.ibge.gov.br. Acessado em 12 dez 2009.

INCRA. Instituto de Colonização e Reforma Agrária. Assentamentos em Santa Catarina em 2008. Disponível em www.ibge.gov.br. Acessado em 12 dez 2009.

LEITE, S.P.; ÁVILA, R.V. Um futuro para o campo: reforma agrária e desenvolvimento social. Rio de Janeiro: Vieira \& Lent, 2007.

LOCH, C.; ERBA, D.A. Cadastro Técnico Multifinalitário: rural e urbano. Cambridge, MA: Lincoln Institute of Land Policy, 2007. 142p.

MDA. Ministério do Desenvolvimento Agrário. Assentamentos da reforma agrária em Santa Catarina. Disponível em www.mda.gov.br. Acessado em 12 dez 2009.

MARIGHELLA, E.T. A questão agrária: textos dos anos sessenta. São Paulo: Editora Brasil Debates, 1980.

MEDEIROS, L.S. História dos movimentos sociais no campo. Rio de Janeiro: Fase, 2002.

MUNARIM, A. Educação e esfera pública na serra catarinense: a experiência política do Plano Regional de Educação. Florianópolis: EdUfsc, 2000. 
NEUMANN, P.S. O impacto da fragmentação e do formato das terras nos sistemas familiares de produção. Florianópolis, 2003. Tese (Doutorado em Engenharia de Produção). Programa de PósGraduação em Engenharia de Produção da Universidade Federal de Santa Catarina.

PEREIRA, S.A. O crédito fundiário como mecanismo de acesso a terra: estudo de caso no município de Cerro Negro- Santa Catarina. 137p. Dissertação (Mestrado em Agroecossistemas) Centro de Ciências Agrárias, Universidade Federal de Santa Catarina. Florianópolis, 2006

PEREIRA, J.M.M. O modelo de reforma agrária de mercado do Banco Mundial em questão: o debate internacional e o caso brasileiro. Teoria, luta política e balanços de resultados. Mestrado (Programa de Pós-Graduação em Desenvolvimento, Agricultura e Sociedade). Centro de Pesquisa e Desenvolvimento da Agricultura, Universidade Federal Rural do Rio de Janeiro, 2004.

PEIXER, Z.I. A cidade e seus tempos: O processo de constituição do espaço urbano em Lages. Lages: Editora UNIPLAC, 2002.

SANTA CATARINA. Governo do Estado. Mapa da região serrana de Santa Catarina. Disponível em www.sc.gov.br. Acessado em 12 dez 2009.

SEYFERTH, Giralda. Identidade nacional, diferenças regionais, integração étnica e a questão migratória no Brasil. In: Região e Nação na América Latina (ZARUR, J. C. L., ed.). Brasília: Editora da UNB: São Paulo: Imprensa Oficial do Estado, 2000, p. 81 - 109 